\title{
From Return-Oriented to Integration-Related Transnationalisation: Turkish Migrants in Germany
}

D'une orientation au retour à une intégration en lien avec les pratiques transnationales : les migrants turcs en Allemagne

De una orientación hacia el regreso a una integración ligada a las prácticas transnacionales: los migrantes turcos en Alemania

Von rückkehrorientierter zu integrationsbezogener Transnationalisierung:

Türkische Migranten in Deutschland

\section{Eveline Reisenauer and Jürgen Gerdes}

\section{QpenEdition}

\section{Journals}

Electronic version

URL: https://journals.openedition.org/remi/5797

DOI: 10.4000/remi.5797

ISSN: $1777-5418$

Publisher

Université de Poitiers

Printed version

Date of publication: 1 March 2012

Number of pages: $107-128$

ISBN: 979-10-90426-03-0

ISSN: 0765-0752

\section{Electronic reference}

Eveline Reisenauer and Jürgen Gerdes, "From Return-Oriented to Integration-Related

Transnationalisation: Turkish Migrants in Germany", Revue européenne des migrations internationales [Online], vol. $28-n^{\circ} 1$ | 2012, Online since 01 March 2015, connection on 15 April 2022. URL: http:// journals.openedition.org/remi/5797 ; DOl: https://doi.org/10.4000/remi.5797 


\section{From Return-Oriented to Integration- Related Transnationalisation: Turkish Migrants in Germany}

\section{Jürgen GERDES ${ }^{1}$ and Eveline REISENAUER ${ }^{2}$}

\section{INTRODUCTION}

Tt was over 50 years ago, on 30 October 1961 that the bilateral agreement on

the recruitment of Turkish migrant workers was signed between Germany and Turkey. The main event to celebrate this anniversary, held at the Federal Foreign Office in Berlin in early November 2011, was attended by Turkish Prime Minister Tayyip Erdoğan and German Chancellor Angela Merkel. In her speech, Merkel emphasised that the event was an expression of thanks to those who came to Germany and helped to shape the country.

The German-Turkish recruitment agreement was originally concluded due to economic considerations of the two nation-states involved. While the economic growth in Germany since the early 1950s and the 'economic miracle' created a demand for additional foreign workers, particularly in the industrial and agricultural sectors, the Turkish government regarded the export of surplus labour power as an aspect of development policy that would reduce unemployment and result in a flow of remittances. Between 1955 and 1968, Germany also signed several other recruitment agreements with countries such as Italy, Spain, Greece, Morocco, Portugal, Tunisia and Yugoslavia. The Turkish migrants, however, became the largest immigrant group, with more than 2.5 million people of Turkish 'immigrant background' currently living in Germany.

While migration to Germany was basically seen as a temporary phenomenon at the time the countries entered into the recruitment agreement, as was also reflected in the term 'guest workers', it is now generally perceived as resettlement into another

1 Dipl.-Pol. Faculty of Educational Studies, Institute for Sociology, University of Education Freiburg, Kunzenweg 21, 79117 Freiburg, Germany; juergen.gerdes@ph-freiburg.de

2 Dipl.-Soc. Faculty of Sociology, Bielefeld University, PO Box 100131, 33501 Bielefeld, Germany; eveline.reisenauer@uni-bielefeld.de 
country. Since the 1990s, in view of the large population of de facto immigrants, the public discourses and the politics and policies in Germany have increasingly moved away from the German government's formerly dominant official view that Germany is not, and should not be, a country of immigration. The recent events to celebrate 50 years of Turkish immigration to Germany would hardly have been imaginable without the paradigm shift Germany experienced with regard to immigrant integration. In her speech, the German Chancellor also specifically gave examples of the successful integration of Turkish immigrants into German society. In the public discourse and traditional integration approaches, integration is often seen as a process of settlement in the receiving society which goes along with breaking off relationships to the country of origin at the latest by the so-called second generation.

At the same time, studies on the transnationalisation of Turkish migrants in Germany provide evidence of cross-border practices in various spheres of social life (see, among others, Faist and Özveren, 2004). This leads to the question of how integration-related and transnational practices of Turkish migrants interact with each other. Does integration in Germany weaken the cross-border practices of Turkish migrants? Or, conversely, do transnational practices of Turkish migrants prevent their integration into the immigration country? These questions will be examined in the following sections based on empirical data drawn from the German survey of the project "Transnationalisation, Migration and Transformation: Multi-level Analysis of Migrant Transnationalism" (TRANS-NET). ${ }^{3}$

The TRANS-NET project involved partners from eight countries, which were grouped in four pairs: Estonia/Finland, India/UK, Morocco/France and Turkey/Germany. This multi-sited research design (Marcus, 1995) allowed us to consider both sides of the migration process, focusing as it did not only on migrants in the immigration country but also on their (often immobile) significant others in the emigration country. The primary research question of the TRANS-NET project was: How do cross-border practices of migrants emerge, function and change? Processes of transnationalisation were analysed in the political, economic, sociocultural and educational spheres (cf. Pitkänen et al., 2012).

The sample of the German TRANS-NET project survey included 73 qualitative interviews with Turkish citizens living in Germany, German citizens who were once Turkish citizens and German citizens at least one of whose parents was (formerly) a Turkish citizen. As a result, the group of respondents consisted of former 'guest workers', asylum seekers, marriage migrants, family-based migrants, German-born children of Turkish migrants, foreign degree students and high-skilled labour migrants. The respondents were also diverse in terms of personal characteristics such as gender, age, education, marital status and place of residence. However, the German sample is not representative, despite its heterogeneity.

The primary aim of the survey was to identify patterns of transnational practices, relationships and orientations that are characteristic of Turkish migrants. In the following sections, we will show that due to significant changes in the political and institutional

3 We would like to thank the European Commission which funded the project under the Seventh Framework Programme of the European Union from March 2008 to February 2011. 
opportunity structures the transnational practices of the Turkish migrants surveyed did not delay or prevent their integration, but rather interacted with and were embedded in integration-related practices.

Before we describe the relationships between integration-related and transnational practices in detail, we will discuss the existing theories on migrant incorporation: assimilation, multiculturalism and transnationalisation. We will then provide a brief history of how Germany came to describe itself as an 'immigration country', a process which, as we shall argue, led to a significant transformation of the institutional and political opportunity structures for the practices and orientations of migrants. Using empirical data from the German TRANS-NET survey, we will present the predominant transnational patterns observed among Turkish migrants and their descendants, ranging from return to Turkey to settlement in Germany, within the previously predominant opportunity structure of homeland orientation. We will also describe the more recent transnational practices of Turkish migrants, which coincide with their integration-related activities and correspond with a significantly changed opportunity structure that promotes integration on different levels. In the fourth section we will present a typology, which we developed to get a more detailed picture of different types of migrant practices. In the final section, we will discuss the correlation between integration-related and transnational practices, based on selected interviews for the political, economic and sociocultural spheres.

\section{MODES OF INCORPORATION: ASSIMILATION, MULTICULTURALISM AND TRANSNATIONALISATION}

Traditional approaches in migration research often conceptualise spatial mobility of migrants as a one-time unidirectional relocation from one nation-state to another (e.g., Eisenstadt, 1953: 169). The research interests of such authors are focused primarily on processes and conditions of migration to and integration into immigration countries. Traditional assimilation theories assume that immigrant adaptation to the culture of the receiving country necessarily goes along with an increasing loss of previous ethnic identification and homeland orientation. According to the concept of immigrant assimilation developed by Milton M. Gordon (1964), for example, immigrant integration is strongly associated with an adaptation of minority groups to the majority's society and culture.

Multicultural approaches to integration, by contrast, contend that integration can proceed without requiring the newcomers to deny or renounce their ethnic and religious identities. Indeed, according to theories of multicultural citizenship, the official recognition of the migrants' cultures, languages and religions by the institutions of the receiving country are a precondition for successful integration (cf. Kymlicka, 1995). To overcome the limitations of Gordon's concept, Richard Alba and Victor Nee (2003) developed the 'new assimilation theory', in which the receiving society is no longer conceptualised as a static and homogeneous unit, and assimilation is no longer the one-sided adoption of the majority culture by the immigrants. Rather, it is described as a dynamic two-way process, which involves transformations of both the minority groups and the majority practices and institutions. Alba and Nee (2003: 11) note that, "assimilation, as a form of ethnic change, may occur through changes taking place in groups on both sides of the 
boundary. Consequently, we define assimilation as the decline of an ethnic distinction and its corollary cultural and social differences."

The main point to be stressed here is that the existing concepts of assimilation usually ignore the relationships migrants have with their emigration country, and that those concepts which focus on the transnational nature of migration assume that it decreases after being in the immigration country for a longer period of time. For example, according to Robert E. Park (1950: 350), migration "involves, at the very least, changes of residence and the breaking of home ties." Processes of immigrant assimilation are believed to be accompanied by an increasing loss of previously existing orientations, relationships and practices with regard to the emigration country, a process that is thought to begin latest in the 'second and subsequent generations' (see also Itzigsohn and Saucedo, 2002). Also, integration theories in Germany tend to treat assimilation, multiculturalism and transnationalisation as mutually exclusive, with bilingualism (Esser, 2006) and bicultural lifestyles (Heitmeyer et al., 1997), in particular, being perceived as obstacles to the assimilation of immigrants in the receiving society.

For about two decades, however, migration and integration theories centred on nation-states have been challenged by transnational approaches. In the 1990s the work of the anthropologist Nina Glick Schiller and her colleagues made a major contribution to the review of previous one-sided concepts and approaches in migration research, written primarily from the perspective of immigration countries. Glick Schiller and her team presented a new analytical framework for the study of contemporary migration, which could account for the empirical evidence that migrants arrange their lives across the borders of nation-states. Today's migrants no longer have the same migration experiences as the migrants of the late nineteenth and early twentieth centuries. Rather, they "develop and maintain multiple relations - familial, economic, social, organizational, religious, and political that span borders. Transmigrants take actions, make decisions and feel concerns, and develop identities within social networks that connect them to two or more societies simultaneously" (Glick Schiller et al., 1992: 1-2.).

This new perspective, which involves the analysis of multiple and bidirectional forms of cross-border mobility and relationships, enables researchers to focus on both the immigration country and the emigration country. By considering the "growing number of persons who live dual lives: speaking two languages, having homes in two countries, and making a living through continuous regular contact across national borders" (Portes et al., 1999: 217), transnational approaches introduce an alternative analytical perspective in migration research.

Transnationally engaged migrants fit neither the temporary immigrant model of the 'guest workers' nor the 'settler model' of immigration (Kivisto, 2005: 23). Unlike temporary immigrants, transnational migrants do not necessarily return to their emigration country to stay there permanently, but may stay in the immigration country while maintaining transnational relationships or continue to travel back and forth between the two countries. Contrary to the mode of integration described by assimilation theories, transnational relationships and practices do not necessarily decrease the longer the migrants stay in the immigration country, nor do they decrease over successive genera- 
tions. Transnationalisation represents a type of migration pattern, in which "migration and re-migration are not definitive, irrevocable, and irreversible decisions. Transnational lives in themselves may become a strategy of survival and betterment." (Faist, 2000: 200)

However, the original concept of transnationalisation developed by Nina Glick Schiller and her colleagues, which regarded contemporary transmigrants as different from previous groups of immigrants, was called into question from two different perspectives. Not only is transnationalisation, historically speaking, not a new phenomenon, considering that there have been transnational migrants in the past (see, in particular, Foner, 2001 ); it is also doubtful whether the phenomenon of transnationalisation as it is observed today can be generalised to include the entire migrant population. Instead, it is asserted that the original concept overemphasised the extent of transnationalisation among contemporary migrants (Portes, 2001: 182; Guarnizo et al., 2003: 1212). Thus, the clear distinction between temporary migrants and settled immigrants in the past and transmigrants today is considered inadequate.

As we will discuss later, the research on Turkish migrants in Germany has revealed empirical evidence of all three modes of incorporation. A certain percentage of the Turkish labour migrants and their families returned to Turkey, while others remained in Germany. Some of those who remained fit more closely with the assimilation model of immigration because in their cases transnationalisation was only a transitional stage of the assimilation process (Faist, 2007: 239). In other cases transnational practices continued or even increased as the migrants settled in Germany. These observations indicate that the orientations and practices of migrants in terms of assimilation, multiculturalism or transnationalisation may change during their lives. Moreover, we will argue on the basis of empirical findings that migrants may also be able to combine aspects of all three modes of incorporation simultaneously if their individual situation and the social and political contexts allow for it.

More recent transnational approaches do not regard assimilation, multiculturalism and transnationalisation as mutually exclusive theoretical models but rather as a set of interrelated concepts (Kivisto, 2005: 24). According to this view, "assimilation is consistent with continued transnational links." (Faist, 2007: 239) With both modes of incorporation - assimilation and transnationalisation - providing valuable insights into the current processes of integration, multi-perspective analysis is a particularly useful method to explore contemporary migration patterns (Faist, 2003). In addition, processes of structural integration can coincide with migrants becoming or being involved in ethnic networks and the development of particular bicultural skills, a finding that calls into question the predominant political discourses on the "return of assimilation" (Brubaker, 2001) and the alleged "multiculturalism backlash" (Vertovec and Wessendorf, 2010).

The extent to which migrants favour strategies of assimilation, multiculturalism or transnationalisation depends, among other things, on the political and institutional opportunity structures in the immigration countries (cf. Koopmans et al., 2005), which include not only the national residence and citizenship requirements and employment avenues, but also the predominant public perceptions and discourses on immigration and immigrants. The following section will provide a brief overview of two different, successive 
opportunity structures in Germany, which led to the development of transnational orientations among Turkish migrants. However, the transnational orientations and practices differ greatly in terms of compatibility with the migrants' integration-related opportunities and efforts. While in the first period a 'guest worker'-related opportunity structure promoted "homeland-directed transnationalism" among Turkish migrants, Germany's new integration policy regime promotes "country of residence-directed transnationalism" (Koopmans et al., 2005: 126ff.; cf. also Østergaard-Nielsen, 2003) which, in many cases, is a kind of by-product of integration-related aspirations.

\section{CHANGING INSTITUTIONAL OPPORTUNITY STRUCTURES: GERMANY'S SELF-IMAGE AS AN 'IMMIGRATION COUNTRY'}

For a long time, the official position of the German government was that Germany was not, and should not be, a country of immigration, despite the fact that after the Second World War West Germany had become the largest immigrant-receiving country in Europe. Officially, the government was able to deny the reality of immigration to Germany because the return of some four million re-settlers (Aussiedler) of German descent between 1950 and 1989 was not regarded as immigration but as the fulfilment of the country's historical responsibility to protect the descendants of former German emigrants to East European countries, who were deemed victims of persecution and forced resettlement during and after the Nazi regime because of their ethnic German origin. Another reason was that the recruitment of 'guest workers' between 1955 and 1968 had always been regarded as temporary migration. For a long time, all of the parties involved - the German government, the sending states and the migrants themselves - believed that the 'guest workers' would return 'home' one day (Joppke, 1999: 65). Although processes of permanent settlement began in the 1970s, the "myth of return" (Martin, 2004: 228) prevailed, kept alive by politicians in particular.

According to the Foreigner Law of 1965 , which was not replaced by a new law until the German reunification in 1990, the granting of residence permits was only a matter of state discretion, with the state essentially having to consider its own interests. Most importantly, renewals and first-time applications were treated equally - a legal way for government agencies to prevent immigrants from staying permanently (cf. Davy, 2005). The extremely restrictive Citizenship Law provided that birthright citizenship could only be conferred by jus sanguinis and naturalisation was only allowed, as a matter of state discretion, after fifteen years of legal residence, and it was not until the year 2000 that this law was partly revised. In the 1980 s the newly-elected coalition government led by the Christian Democrats provided for financial incentives to encourage the voluntary return of former 'guest worker' families.

By that time, however, it was already obvious that a strict 'guest worker' rotation regime could not be enforced for several reasons. One major reason was that German employers did not want to see their trained immigrant workers replaced by newcomers who had had no work experience at their factories. Another was that the ban on the recruitment of foreign workers in 1973 - the government's response to the economic recession following the oil crisis - led to an unintended increase in family migration. Many migrants, 
afraid that they would not be permitted re-entry once they had left Germany, decided to stay longer and to reunify with their families to the extent possible. But perhaps the most important reason why it was not feasible to temporarily put a stop to 'guest worker' migration was that a number of important rulings of the administrative and constitutional courts rejected the notion of unconditional state discretion, arguing that claims of noncitizens in cases such as deportation refusal, residence permit extension and family reunification were legitimate because they were covered by the provisions on the protection of human rights enshrined in the Basic Law (cf. Joppke, 1999: 72ff.; Davy and Çinar, 2001). However, despite all these indications of a transition of 'guest worker' migration to permanent settlement, the responsible German governments continued the 'no country of immigration' policy instead of creating sustained immigrant integration policies at the federal level.

With the German reunification in 1990 the return-oriented political and institutional opportunity structures began to change gradually, a development that ultimately led to a paradigmatic immigration policy change. The first steps had already been taken. The reform of the Foreigner Law modified the one-sided focus on administrative discretion by providing for individual rights of residence and the improvement of the residence status over time, thus enhancing legal clarity, certainty and predictability (Davy, 2005: 132). This was followed by the enactment of the new Nationality Law in 2000 and the comprehensive Immigration Law in 2005. The Nationality Law of 2000 acknowledged the immigrations of the past by significantly easing the citizenship requirements for immigrants (e.g., by reducing the required residence period for naturalisation from 15 to 8 years) and their descendants (by introducing a jus soli for the 'second generation') who had already resided in Germany for many years. The 2005 Immigration Law allowed for additional regular immigration of highly skilled migrants and of entrepreneurs who are willing to make substantial investments. The idea emerged that Germany should join the "race for talent" (Shachar, 2006) and seek to attract highly skilled migrants in particular. However, in the following years it turned out that the most decisive policy transformation was the one concerning the integration of immigrants. For the first time, the new immigration law defined immigrant integration as a responsibility of the state (Groß, 2006), addressing the issue in a separate chapter that provided for integration training, including German language courses and courses on German politics and society.

During the term of the grand coalition government between Christian and Social Democrats from 2005 to 2009 , immigrant integration was one of the issues that dominated the political and public debates in Germany. The government held several high-level 'integration summits' with representatives of various government institutions, social groups and migrant organisations. One of the outcomes of the summits was the National Integration Plan (NIP), in which the participants adopted a large number of commitments relating to supporting integration processes on different levels. During this period, a consensus emerged across the political parties that immigrant integration was an important objective, which should be pursued by many institutions and societal actors on various levels of government. These developments can be characterised as a paradigmatic - or, rather, a "transformative" - policy change (Hall, 1993), considering that not only have the means and instruments changed, but the goals, values and norms themselves and the overall philosophy have changed as well. 
These transformations are also reflected in new or newly-defined technical terms and descriptions, such as 'integration commissioner' which replaced the term 'commissioner of foreigners' and, more importantly, the now commonly used 'people with a migration background' which came to replace the term 'foreigners', comprising non-citizens, naturalised German citizens and anyone who has at least one parent with migration experience. This definition added a new dimension to the issue: the number of 'persons with a migration background' currently living in Germany amounts to about 15 million, or one fifth of the country's population, with the proportion of young people with a migration background growing steadily. Recent years have seen a proliferation of studies on integration and numerous publicly funded integration-related initiatives.

To appreciate quite how far-reaching the paradigmatic shift in Germany's integration policy really is, we should consider that it is embedded in parallel transformations of other policy areas, such as economic, labour market, family and education policies (cf. Gerdes, 2010). The predominant rationale behind recent policy reforms has been to activate human capital and encourage labour market participation of previously underutilised groups such as women, the elderly and 'persons with a migration background' (cf. Lessenich, 2008), which is regarded as an appropriate strategy to enhance economic competitiveness in a 'knowledge-based society', to deal with the demographic issue of an increasingly aging population and to maintain the financial operability of social security systems. Integration is considered to be of "national relevance" (NIP: 12), the most urgent integration-related issues addressed being comparatively lower education and skill levels, higher unemployment rates and greater dependence on social benefits among 'persons with a migration background'.

\section{TURKISH MIGRANTS BETWEEN RETURN AND SETTLEMENT}

The results of our research on Turkish migrants provide evidence of both of these different opportunity structures that led to the emergence of different forms of transnational practices. The fact that Germany officially denied being an immigration country for decades and the country's restrictive institutional and political opportunity structures obviously contributed to the sustained homeland orientation and practices among Turkish migrants. Traces of the fact that the migrants originally planned to return - a return that in many cases was postponed indefinitely - and of the way it has shaped the biographies of Turkish migrants are still evident in the narratives of our respondents.

A common practice among migrants who originally intended to return was to maintain their relationships with Turkey (see Itzigsohn and Saucedo, 2002: 784). This return orientation had consequences not only for the individual migrant workers of the first generation themselves, but also for their families, especially their children. Some of the 'second-generation migrants' we interviewed talked extensively about the effects this permanent return orientation of their families had on their own life plans, their educational and occupational careers and their personal relationships.

Initially, the Turkish 'guest workers' went to Germany mainly for economic reasons. Many of them arrived hoping to improve their income and the living conditions 
of their families in Turkey. ${ }^{4}$ Most of the former labour migrants we interviewed for the TRANS-NET project in Germany and Turkey told us that they have sent some of their income back home to Turkey, where the money was used to cover the monthly expenses of the core family or the extended family and to make investments. The Turkish migrants tried to save enough money to build a house, buy an apartment or start a small business after their return to Turkey. Some of the Turkish citizens eventually went back to Turkey, either because they were offered financial incentives by the German government or because they had personal reasons to do so, such as school problems of their children, unemployment or xenophobia in Germany, or family commitments in Turkey (Abadan-Unat, 1988; Martin, 1991: 38ff.). However, for many Turkish migrants, what was originally supposed to be temporary labour migration eventually turned into permanent settlement. Halil ${ }^{5}$, for example, a German-born interviewee from the German TRANS-NET survey, told us that his father had initially come to Germany to save enough money to buy a tractor in Turkey, but the family never went back. "Two generations for one tractor..." as he summed up the situation.

Many Turkish migrants cherish the "illusion" (Pagenstecher, 1996) that they will go back to Turkey someday, but never actually make a decision about their stay in Germany and postpone their return to Turkey for years. Dilek, an interviewee from the '1.5 generation', now 44 years old, stated:

\begin{abstract}
"Yes, and then it [the planned return migration of the family] was postponed to the next year. In this respect, in a sense, we lived out of our suitcases. Everything was prepared for the return next summer. The money was saved, saved and saved. 'Next year we will go back forever.' That had a negative effect on me, because you can't set yourself proper goals. Also, in terms of education, career plans or friendships, I didn't want my emotional ties to become too strong, because I kept thinking that I'd go back the following year anyway. As far as these things were concerned, I never really felt at home."
\end{abstract}

Many of the interviewees who had come to Germany as children or adolescents stated that they had very poor German language skills during their school days as a result of their migration experience, which in many cases diminished their educational career opportunities. Some of our respondents noted that placing Turkish children into special Turkish classes during the early period of Germany's 'guest worker' regime to ensure their re-integration into the Turkish society after their expected return had similar results.

While some of the Turkish migrants we interviewed had abandoned their relationships with Turkey after their family had been reunified in Germany, when they did not have enough time or money for travelling, or when their relatives in Turkey had also emigrated or died, other Turkish migrants and their descendants maintained long-lasting relationships between Germany and Turkey.

4 Many of the Turkish migrants interviewed were separated from their spouses, children and other relatives while in Germany and maintained "transnational families" (Landolt and Da, 2005: 625) until family reunification, often for years.

5 The names of the persons interviewed in the German survey of the TRANS-NET project were changed to ensure their anonymity. 
One such case was the Kaymaz family. For the TRANS-NET project we interviewed the father, Ogün, one of his daughters, Cansel, and her husband, Halil, in Germany and another daughter in Turkey. In 1963 Ogün Kaymaz migrated to Germany as a 'guest worker', where he lived without his family for about twenty years. During this time, he always sent money to his core family back home:

"I've sent a lot of money to Turkey, you know? Yes, three hundred or five hundred German marks every month, you know? For example, when my daughter sent me a letter, 'Baba, I want to go to school and I need five hundred marks for that', I sent more money."

Later, some members of the family joined him in Germany. His daughter Cansel could not go with them because she was over 16 years old at the time and therefore not allowed to come to Germany under the family reunification plan. It was only when she married Halil, the German-born son of her father's best friend, in 1995 that she could migrate to Germany as well. Over the years, most of the family members moved back and forth between Turkey and Germany several times. Today, Ogün, his wife and two of his adult daughters and their families live in Germany, and his two other daughters live in Turkey. The members of the extended family are scattered across Germany and Turkey call each other regularly:

"We call each other every day. [...] Just to say hello, how are you, how is the weather, what is the family doing? [...] It's a little expensive, but you have to talk to each other. [...] Sometimes only for two or three minutes, that's enough."

The 72-year-old Ogün is now retired and, like many former labour migrants in retirement, he travels back and forth between Germany and Turkey (see also Krumme, 2004):

"Then I stay in Turkey for five or six weeks or for two or three months during the summer. In the winter I come back to Germany."

"Pensioners have to go home", as Ogün explains his recurrent stays in Turkey.

Like the Kaymaz family, many of the respondents in the German TRANS-NET survey became settled immigrants in Germany but continued to engage in transnational practices. These cases raise the question of the relationship between transnationalisation and integration among Turkish migrants and their descendants: Do transnational practices prevent their integration in Germany, or can transnational and integration-related practices exist simultaneously? To be able to answer this question, we need a more detailed understanding of the different types of transnational practices observed among Turkish migrants today. 


\section{THE VARIETY OFTRANSNATIONAL PRACTICES: ATYPOLOGY}

When the analysis of our interview data revealed a wide variety of transnational practices among Turkish migrants, we decided to develop a typology of these practices. (The classification parameters and criteria are listed in Table 1 below.) In accordance with the research design of the TRANS-NET project, the first step was to classify the practices according to their function in the political, economic or sociocultural sphere of social life. This classification is consistent with common classifications of transnational spaces in the literature (see, among others, Faist, 2000; Vertovec, 2009). The political sphere includes political interest, attendance at political events, membership in political organisations and various types of political participation. In the economic sphere, the focus is on the production and exchange of goods, capital and knowledge, the provision of services and the deployment of manpower and personnel. The sociocultural sphere was defined as social engagement (participation and membership in social networks, associations and organisations) and individual and organised forms of social help and support, including family care. So, the first step in the development of the typology was to analyse the transnational practices in the selected countries on the basis of the classification of the spheres of social life. The next two steps involved the comparison of the individual cases during the analysis of the data from the German survey.

The second step was based on the observation that nearly all of the interviewees are characterised by transnationality, albeit to different degrees. ${ }^{6}$ To be able to consider the entire range of transnational practices observed in the survey data, transnationality was conceptualised as a continuum of transnational practices, classified into the categories 'strong', 'moderate' and 'weak'. These categories relate to the intensity of transnational practices in terms of frequency and social and institutional involvement. In this model, transnational practices are considered 'strong' if they occur regularly, and 'weak' if they occur at least occasionally. In addition, the degree of transnationalisation is considered inversely proportional to the degree to which the interviewees pursued their personal interests and directly proportional to their involvement in larger collectives such as families or organisations and, thus, their repertoire of formalised roles and functions. The specific components of the categories in the various spheres of social life were derived from the survey data through a continuous comparison of the interviews.

During the analysis of the empirical data it became evident that current transnational practices are accompanied by integration-related practices. In the overwhelming

6 Although the German survey showed a generally high degree of physical mobility, relatively few of the respondents had 'transnational life worlds' or were residents of both countries. According to Peggy Levitt (2001b: 198), three types of migrants can be distinguished: frequent travellers, periodic movers and "those who do not move but who live their lives within a context that has become transnationalized." The typology accentuates the fact that migrants who only move occasionally and even those who are immobile can be involved in transnationalisation as well.

7 The distinction between 'strong' and 'weak' transnational practices is consistent with similar distinctions in the literature, where a distinction is made either between 'narrow' and 'broad' forms of transnationality (Itzigsohn et al., 1999: 323; Itzigsohn and Saucedo, 2002: 770) or between 'core' and 'expanded' transnational practices (Guarnizo et al., 2003; see also Levitt, 2001b: 198), with the former pair of terms referring to continuous participation in transnational practices, and the latter to sporadic or irregular transnational practices. 
majority of cases, the transnational practices of Turkish migrants and their descendants were part of their efforts towards nation-state-based integration rather than an alternative to it. Therefore, the third step was to draw a conceptual distinction between transnational practices which transcend the borders of nation-states and integration-related practices which occur in Germany, with 'integration-related practices' referring not only to relationships with the 'majority society', but also to intra-ethnic practices or combinations of intra-ethnic and inter-ethnic relationships in Germany.

Table 1: Typology of transnational and integration-related practices in different spheres of social life

\begin{tabular}{|c|c|c|c|c|}
\hline & \multicolumn{3}{|c|}{ Transnational practices } & \multirow{2}{*}{$\begin{array}{l}\text { Integration- } \\
\text { related practices }\end{array}$} \\
\hline & Strong & Moderate & Weak & \\
\hline 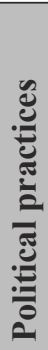 & $\begin{array}{l}\text { Membership and } \\
\text { participation in } \\
\text { the non-resident } \\
\text { country or } \\
\text { transnational } \\
\text { political } \\
\text { organisations; } \\
\text { Extra-territorial } \\
\text { voting }\end{array}$ & $\begin{array}{l}\text { Cooperation } \\
\text { with parties or } \\
\text { organisations } \\
\text { abroad as a } \\
\text { member of } \\
\text { resident country- } \\
\text { based (migrant) } \\
\text { organisations }\end{array}$ & $\begin{array}{l}\text { Interest in the } \\
\text { politics and } \\
\text { policies } \\
\text { of other countries } \\
\text { or transnational } \\
\text { political actors } \\
\text { and institutions }\end{array}$ & $\begin{array}{l}\text { Political } \\
\text { participation or } \\
\text { functions related } \\
\text { to migration, } \\
\text { integration or } \\
\text { intercultural } \\
\text { relations in } \\
\text { Germany }\end{array}$ \\
\hline 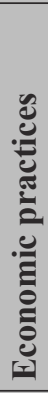 & $\begin{array}{l}\text { Transnational } \\
\text { entrepreneurship } \\
\text { or occupational } \\
\text { functions based } \\
\text { on cross-border } \\
\text { exchange of } \\
\text { goods, capital, } \\
\text { services, } \\
\text { knowledge or } \\
\text { labour }\end{array}$ & $\begin{array}{l}\text { Occasional } \\
\text { occupational } \\
\text { involvement } \\
\text { in cross-border } \\
\text { exchange of } \\
\text { goods, capital, } \\
\text { services, } \\
\text { knowledge or } \\
\text { labour }\end{array}$ & $\begin{array}{l}\text { Use of certain } \\
\text { transnational } \\
\text { skills or resources } \\
\text { for occupational } \\
\text { activities }\end{array}$ & $\begin{array}{l}\text { Ethnic } \\
\text { entrepreneurship; } \\
\text { Occupational use } \\
\text { of ethnic skills } \\
\text { or opportunities } \\
\text { without relations } \\
\text { to other countries }\end{array}$ \\
\hline 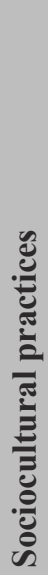 & $\begin{array}{l}\text { Membership } \\
\text { and participation } \\
\text { in non-resident } \\
\text { country or } \\
\text { transnational } \\
\text { networks or } \\
\text { organisations; } \\
\text { Continuous } \\
\text { participation in } \\
\text { organised forms } \\
\text { of cross-border } \\
\text { help and support }\end{array}$ & $\begin{array}{l}\text { Occasional } \\
\text { participation in } \\
\text { organisations } \\
\text { abroad or } \\
\text { transnational } \\
\text { networks; } \\
\text { Continuous } \\
\text { informal cross- } \\
\text { border help and } \\
\text { support activities } \\
\text { (including } \\
\text { transnational } \\
\text { family care) }\end{array}$ & $\begin{array}{l}\text { Participation } \\
\text { in migrant } \\
\text { organisations } \\
\text { which } \\
\text { occasionally } \\
\text { cooperate with } \\
\text { organisations in } \\
\text { other countries; } \\
\text { Sporadic } \\
\text { informal cross- } \\
\text { border help and } \\
\text { support activities } \\
\text { (including } \\
\text { transnational } \\
\text { family care) }\end{array}$ & $\begin{array}{l}\text { Individual } \\
\text { or organised } \\
\text { initiatives to } \\
\text { support migrant } \\
\text { integration } \\
\text { and interethnic } \\
\text { relations in } \\
\text { Germany } \\
\text { (including family } \\
\text { care) }\end{array}$ \\
\hline
\end{tabular}


Only a few respondents who participated in our survey engaged in transnational practices in all three spheres of social life simultaneously. In most of the cases, transnationalisation was observed either in only a few or even just one sphere, or in several spheres, but to different degrees. Therefore, transnationalisation must be evaluated with regard to the scope of transnational practices in the different spheres of social life (Levitt, 2001b: 198). For example, while some migrants regularly engaged in transnational practices in only one sphere, occasional transnational practices often occurred in more than one sphere simultaneously. Most of the transnational practices in our survey were observed in the economic sphere, most often occurring on a more regular basis, while transnational practices in the political and sociocultural spheres were less pronounced.

In addition, the different social spheres showed variations in transnationalisation with regard to the educational and occupational background of our respondents. While the respondents engaged in transnational practices in the sociocultural sphere regardless of their educational background, economic and political transnational practices were found primarily among the better-educated Turkish migrants and their descendants. The fact that respondents with different levels of education engage in transnationalisation shows that marginalised migrants who are not (yet) integrated are not the only ones engaging in transnational practices, as is often contended in traditional assimilation theories. Rather, it appears that better-educated migrants are more able to make use of political and economic transnational opportunities.

The empirical data shows that transnational practices were often part of the migrants' regular work activities or their voluntary involvement in the activities of networks, associations or organisations in Germany. In such cases, transnationalisation went hand in hand with intra-ethnic and inter-ethnic practices in the institutional contexts of immigration countries. Many transnational practices and the skills they involve, such as multilingualism and knowledge of different cultures and institutions, were also beneficial to the respondents' occupational success, thus contributing significantly to their integration in Germany.

Even if assimilation does occur over time, it does not necessarily imply a decrease in transnational practices. Some concepts of assimilation are based on the assumption that social cross-border practices are eventually discontinued as a result of return migration to the country of origin or integration into the receiving country. Transnational approaches, by contrast, recognise that "even those migrants and refugees who have settled for a considerable time outside the country of origin frequently entertain strong transnational links" (Faist, 2000: 200; for the U.S, see Itzigsohn and Saucedo, 2002: 784). The empirical findings of the German TRANS-NET survey do not support the assumption of a direct assimilation path accompanied by a decrease in cross-border practices. In fact, even the respondents who were long-term residents in Germany were involved in transnational practices, which means that transnational practices do not necessarily remain stable over time, but rather "ebb and flow at different stages of individuals' life cycles" (Levitt, 2001a: 20). Reasons for a decrease in transnational practices given in our survey included the death of a significant other in Turkey and the deterioration of the respondents' financial situation. An increase in transnational practices was observed for many retired 'guest workers' who, like Ogün Kaymaz, travel back and forth between the two countries. In 
other cases, relationships with Turkey were only established when migrants engaged in integration-related activities in Germany, such as when their new job involved connections to Turkey.

An important question with which transnational approaches are faced is whether transnationality is a phenomenon that is only characteristic of people with direct migration experiences, or whether it also exists in 'second and later generations of migrants' (e.g., Levitt and Waters, 2002). Many children of Turkish immigrants in Germany grew up in transnational settings, having been left in the care of grandparents or other relatives while their parents worked and lived abroad. Others were brought to the receiving country when they were children or teenagers and had to leave relatives and friends behind. Still others were born in Germany but sent 'home' to be raised there. Many also travelled back and forth between the countries, spending significant periods of their lives both in their parents' emigration country and in the immigration country. They returned with their families to go on holidays or to attend important events such as birthdays and weddings, or stayed in contact with their grandparents and other relatives they had had to leave behind. Some members of the ' 1.5 and second generation' of Turkish migrants maintained these transnational relationships with their grandparents or other relatives all their lives. Others strengthened existing relationships or even established their own transnational relationships with Turkey as adults, for occupational or other reasons.

Transnational practices of the ' 1.5 and second generations' in Germany are often accompanied by generational upward social mobility. Generational transition does not necessarily go along with a decrease in relationships with Turkey in general. Indeed, having grown up in Germany and Turkey, they are able to get involved in two countries at the same time.

In sum, the empirical findings of the German TRANS-NET survey indicate that migrant integration in Germany today essentially involves simultaneously occurring processes of assimilation, multiculturalism and transnationalisation. While it is possible to distinguish between these three processes for the purpose of analysis, in many of the empirical cases they are interrelated and mutually supportive. Respondents' transnational practices in different spheres of social life coincide with their participation in the German context. Moreover, their integration in Germany does not necessarily weaken their crossborder practices, neither while they are in Germany nor from one generation to the next. The German TRANS-NET survey showed that transnational and integration-related practices of Turkish migrants and their descendants in Germany are not mutually exclusive, but occur simultaneously. In the following section we will describe a few selected individual cases from our survey in more detail to illustrate integration-related transnational practices in the political, economic and sociocultural spheres of social life. 


\section{INTEGRATION-RELATED TRANSNATIONAL PRACTICES OF TURKISH MIGRANTS IN GERMANY}

Most of the respondents who participated in the German TRANS-NET survey showed 'weak' transnational practices in the political sphere. None of them was actually a member of a political party, organisation or association in any country other than Germany. One of the few respondents who were more actively involved in political transnationalisation was Adnan. Born in Turkey in 1972, he came to Germany when he was less than a year old. Throughout his childhood in Germany, he never lost contact with his extended family in Turkey. After finishing school, he studied and worked in the United States, where he met and befriended international students from Turkey and gained some international experience. He then moved on to work for an American company in Turkey. This was the first time he did not experience Turkey as a "holiday Turk" . He has been back in Germany for three years and now works for a government agency. His professional activities give him "the opportunity to help shape the integration policy".

The German citizen Adnan's 'migration background' was not an obstacle to finding employment; it actually helped him get his current job, enabling him to facilitate understanding and dialogue between Turkish migrant organisations and the Turkish community in Germany on the one hand and German political and administrative institutions on the other:

"In particular, persons with a Turkish background who play a bridging role do both; they help the [German] government to understand the Turkish position, but they also affect the Turkish community."

In addition to participating in the German political system, he also concerns himself with Turkish politics. As employee of a German government agency, he often works with Turkish political organisations and institutions:

"Professional contacts [to Turkey] have increased since I returned [to Germany] and started to work for the government. I'm engaged in integration politics, and there are a lot of issues that can only be resolved with the help of Turkey."

Adnan's case shows that transnational and multicultural political practices may occur as a kind of by-product of integration-related involvement. ${ }^{9}$ Over the last few years, Adnan's relationships with his family in Turkey have increased. His sister, who also grew up in Germany, lives and works in Turkey, and his parents are planning to return in the near future.

8 According to Adnan, "most Turks living in Germany are 'holiday Turks'. They go to Turkey every year for four or five weeks, but apart from that they don't have any detailed knowledge about their home country. [...] 'Holiday Turks' have an idealised concept of Turkey that doesn't correspond to reality."

9 A recent study on online political practices of migrants found that the majority of websites run by Turkish migrants focus on Germany, with most of the websites written in German and linking to host society websites. In addition, these websites usually focus on issues of migration and integration (Kissau and Hunger, 2010: 252ff.). 
The transnational practices of Turkish migrants in the economic and occupational spheres were more pronounced than those in the political sphere, with 'moderate' and 'strong' economic practices observed also among a considerable number of respondents from the 'second generation', who regarded and used their 'migration background' and the resulting transnational skills to improve their employment opportunities. 'Strong' transnational practices in the economic sphere were observed among respondents who engaged mainly in the cross-border exchange of goods, capital, services and knowledge while residing in Germany and among a smaller group of respondents who frequently travelled back and forth between Turkey and Germany because their work required a high degree of mobility.

One such respondent was the now 55-year-old Turkish citizen Özlem. She has always lived in Turkey and Germany for longer periods of time. In 1971 she immigrated to Germany, where she married her German husband. She returned to Turkey in 1986, but has been back to Germany since 1999, and she is planning to stay for the foreseeable future. Her new partner, with whom she lives in Germany, is of Turkish origin. Her German ex-husband lives with their daughter, who still has German citizenship, in Turkey. Özlem has been self-employed in various lines of business throughout her life and maintained trade relations either with Turkey or with Germany, depending on where she lived. She currently sells evening and wedding dresses to customers of Turkish immigrant origin in Germany. The clothes are made at factories run by family members in Turkey and at other Turkish companies. Özlem and her partner have numerous business contacts in Turkey from the time when they lived there in the past. Özlem communicates via telephone and email, but also occasionally travels to Turkey, always trying to combine her professional and private life:

"I go there [to Turkey] for business for ten days and then try to stay for the weekend, so I can see my daughter. I have just opened my own fashion studio in another [Turkish] city, and when I go there I can only see my daughter for two hours during the stopover at the airport."

When we looked at transnational social engagement, we found that the German TRANS-NET sample contained no cases of 'strong' transnational practice where individual respondents participate directly in non-German or transnational networks, organisations or associations. ${ }^{10}$ However, many of the respondents were involved in professional and voluntary practices in German organisations or Turkish migrant organisations, with 'moderate' and 'weak' transnational sociocultural practices occurring due to the fact that many of the German-based organisations have relationships with Turkey. Some of the organisations are only occasionally involved in sociocultural transnationalisation, while others cooperate with Turkey on a regular basis.

Kamber is an example of the latter. The child of binational parents who had met when his mother was on holiday in Turkey, Kamber has dual citizenship and speaks both German and Turkish. His grandmother and one of his aunts live in Turkey. Kamber has

10 This article focuses exclusively on social engagement in the sociocultural sphere. When personal relationships are considered as well, a different picture emerges. Our data indicated a high degree of 'strong' transnational practices in the respondents' private lives.

REMI 2012 (28) 1 pp. 107-128 
friends there because his parents have a summer house in Turkey. Kamber completed a three-month internship with a company in Turkey. After doing voluntary work for various organisations working in the areas of migration and integration in Germany, he became the manager of a German-Turkish association that "aims to provide a common ground between Germans and Turks." Most of the association's activities are in the cultural sphere. Kamber's management position often involves dealing with people in Turkey:

"As manager of the house [German-Turkish association], I actually have to deal with Turkey almost every day, particularly with ministries and cultural organisations in Turkey. We work closely with foundations in the areas of the arts and culture in Istanbul. We deal with artists in Turkey all the time, whom we invite to events. Also, managers, record companies, whatever, you name it, in all kinds of areas."

Kamber also has a special relationship to a certain foundation in Turkey because a personal friend of his, a 'second-generation Turk', now works there.

\section{CONCLUSION}

In the selected cases described in the previous section, we observed rather 'strong' transnational practices in different spheres of social life, with Adnan being engaged in political, Özlem in economic, and Kamber in sociocultural transnationalisation. In none of the three cases did the respondents' transnational practices conflict with their integrationrelated practices. In fact, they were facilitated by assimilation and multiculturalism in Germany. Moreover, like most of the interviewees in our survey who showed patterns of increased participation in Turkey, the three respondents were actually involved in the German context to a much greater extent. The case studies illustrated that assimilation and multicultural and transnational processes are not mutually exclusive modes of incorporation, but modes that may occur simultaneously. In addition, the fact that two of the respondents - Adnan and Kamber - have a high level of education shows that it is not marginalised migrants alone who maintain transnational practices. That transnationalisation is not at odds with educational success has also been shown by the Comparative Immigrant Entrepreneurship Project (CIEP) conducted in the United States, which found a positive correlation between high school and college achievement and transnational participation (Guarnizo et al., 2003: 1229; Itzigsohn and Saucedo, 2002: 782).

In terms of migration patterns, mobility and citizenship, the three respondents were very different. Özlem originally came to Germany as a marriage migrant, has moved between Turkey and Germany several times and has Turkish citizenship. Adnan, who belongs to the ' 1.5 generation', lived in the United States and Turkey for many years and has German citizenship. Kamber, the third interviewee, was born in Germany and has dual citizenship. Apart from going to Turkey on holidays or to complete his three-month internship, he was relatively immobile compared to the other two. As different as the three respondents were - they had one thing in common. Even though they had all spent several years in Germany, none of them showed a decrease in their transnational practices. They performed professional, entrepreneurial or voluntary transnational practices, while at the same time maintaining private cross-border relationships. Furthermore, their relationships 
with Turkey included both continued and newly-established transnational ties. The cases show that transnational practices are not necessarily reduced by either the length of stay in Germany or the acquisition of German citizenship. These findings are consistent with those of the CIEP survey for the context of the United States, which found that the length of residence in the United States has a positive effect on transnationality, whereas U.S. citizenship has no effect at all (Guarnizo et al., 2003: 1229; Itzigsohn and Saucedo, 2002: 784).

The results of the German TRANS-NET survey presented here indicate that processes of integration in the immigration country, such as access to education or citizenship, do not necessarily imply a decrease in relationships with the country of origin. Conversely, it also means that transnational practices and orientations of migrants do not prevent integration processes. Indeed, the transnational and integration-related practices of Turkish migrants are interrelated processes. A look at the generations confirms this. The respondents of the ' 1.5 and second generations', Adnan and Kamber, not only maintained existing relationships with Turkey, they also created new ones. Thus, stability of transnationality is not restricted to the first generation of Turkish migrants.

However, the combined transnational and integration-related practices of Turkish migrants and their descendants in Germany are obviously related to a change in the political and institutional opportunity structures, which resulted from the politicisation of immigrant integration and the increased public awareness of the issue in recent years. Integration of immigrants is regarded as a responsibility shared by all of the parties involved, at all levels of government and across all sectors of society. That Germany is an immigration country is now officially acknowledged by all major political parties. The increased efforts to facilitate immigrant integration have increased opportunities for migrants to get involved in political and social activities and provided new job opportunities, with 'diversity management' programmes in particular, encouraging immigrants to bring their personal migration-related experiences and skills to bear in the workplace. Examples of these new opportunities include increased efforts by various administrative and public institutions to recruit employees with 'migration backgrounds' who are able to function as intermediaries between institutions in Germany and their own ethnic migrant communities. 


\section{References}

ABADAN-UNAT Nermin (1988) The Socio-Economic Aspects of Return Migration in Turkey, Migration. A European Journal of International Migration and Ethnic Relations, 3, pp. 29-59.

ALBA Richard and NEE Victor (2003) Remaking the American Mainstream: Assimilation and Contemporary Immigration, Cambridge, Mass., Harvard University Press, 384 p.

BRUBAKER Rogers (2001) The Return of Assimilation? Changing Perspectives on Immigration and its Sequels in France, Germany, and the United States, Ethnic and Racial Studies, 24 (4), pp. 531-548.

DAVY Ulrike (2005) Integration of Immigrants in Germany: A Slowly Evolving Concept, European Journal of Migration and Law, 7, pp. 123-144.

DAVY Ulrike and ÇINAR Dilek (2001) Deutschland, in Ulrike Davy Ed., Die Integration von Einwanderern: Rechtliche Regelungen im europäischen Vergleich, Frankfurt/Main and New York, Campus, pp. 277-423.

EISENSTADT Samuel N. (1953) Analysis of Patterns of Immigration and Absorption of Immigrants, Population Studies, 7 (2), pp. 167-180.

ESSER Hartmut (2006) Sprache und Integration: Die sozialen Bedingungen und Folgen des Spracherwerbs von Migranten, Frankfurt/Main, Campus Verlag, 580 p.

FAIST Thomas (2000) The Volume and Dynamics of International Migration and Transnational Social Spaces, Oxford, Oxford University Press, 396 p.

FAIST Thomas (2003) Amalgamating Newcomers, National Minority and Diaspora: Integration(s) of Immigrants from Poland in Germany, in Rosemarie Sackmann, Bernhard Peters and Thomas Faist Eds., Identity and Integration: Migrants in Western Europe, Aldershot, Ashgate, pp. 205-234.

FAIST Thomas and ÖZVEREN Eyüp (Eds.) (2004) Transnational Social Spaces: Agents, Networks and Institutions, Aldershot, Ashgate, $248 \mathrm{p}$.

FAIST Thomas (2007) The Transnational Turn: Migration and Politics, in Ajaya Kumar Sahoo and Brij Maharaj Eds., Sociology of Diaspora: A Reader, Jaipur, Rawat Publications, pp. 227-266.

FONER Nancy (2001) Transnationalism Then and Now: New York Immigrants Today and at the Turn of the Twentieth Century, in Héctor R. Cordero-Guzmán, Robert C. Smith and Ramón Grosfoguel Eds., Migration, Transnationalization, and Race in a Changing New York, Philadelphia, Temple University Press, pp. 35-57.

GERDES Jürgen (2010) Migrants Rights and Immigrant Integration in German Political Party Discourse, Working Paper 90/2010, Bielefeld, COMCAD - Center on Migration, Citizenship and Development.

GLICK SCHILLER Nina, BASCH Linda and BLANC-SZANTON Cristina (1992) Transnationalism: A New Analytical Framework for Understanding Migration, in Nina Glick Schiller, Linda Basch and Cristina Blanc-Szanton Eds., Towards a Transnational Perspective on Migration: Race, Class, Ethnicity, and Nationalism Reconsidered, New York, New York Academy of Sciences, pp. 1-24.

GORDON Milton M. (1964) Assimilation in American Life: The Role of Race, Religion, and National Origins, New York, Oxford University Press, 286 p.

GROß Thomas (2006) Die Verwaltung der Migration nach der Verabschiedung des Zuwanderungsgesetzes, in Michael Bommes and Werner Schiffauer Eds., Migrationsreport 2006: Fakten - Analysen - Perspektiven, Frankfurt/Main and New York, Campus, pp. 31-61.

GUARNIZO Luis E., PORTES Alejandro and HALLER William (2003) Assimilation and Transnationalism: Determinants of Transnational Political Action among Contemporary Migrants, American Journal of Sociology, 108 (6), pp. 1211-1248.

HALL Peter A. (1993) Policy Paradigms, Social Learning, and the State: The Case of Economic Policy Making in Britain, Comparative Politics, 25 (3), pp. 275-296.

HEITMEYER Wilhelm, MÜLLER Joachim and SCHRÖDER Helmut (1997) Verlockender Fundamentalismus: Türkische Jugendliche in Deutschland, Frankfurt/Main, Suhrkamp, 276 p.

ITZIGSOHN José and SAUCEDO Silvia G. (2002) Immigrant Incorporation and Sociocultural Transnationalism, International Migration Review, 36 (3), pp. 766-798.

ITZIGSOHN José, DORE CABRAL Carlos, HERNANDEZ MEDINA Esther and VAZQUEZ Obed (1999) Mapping Dominican Transnationalism: Narrow and Broad Transnational Practices, 
Ethnic and Racial Studies, 22 (2), pp. 316-339.

JOPPKE Christian (1999) Immigration and the Nation-state: The United States, Germany, and Great Britain, Oxford, Oxford University Press, 368 p.

KISSAU Kathrin and HUNGER Uwe (2010) The Internet as a Means of Studying Transnationalism and Diaspora, in Rainer Bauböck and Thomas Faist Eds., Diaspora and Transnationalism: Concepts, Theories and Methods, Amsterdam, Amsterdam University Press, pp. 245-265.

KIVISTO Peter (2005) The Revival of Assimilation in Historical Perspective, in Peter Kivisto Ed., Incorporating Diversity: Rethinking Assimilation in a Multicultural Age, Boulder/CO, Paradigm, pp. 3-29.

KOOPMANS Ruud, STATHAM Paul, GIUGNI Marco and PASSY Florence (2005) Contested Citizenship: Immigration and Cultural Diversity in Europe, Minneapolis and London, University of Minnesota Press, $376 \mathrm{p}$.

KRUMME Helen (2004) Fortwährende Remigration: Das transnationale Pendeln türkischer Arbeitsmigranten im Ruhestand, Zeitschrift für Soziologie, 33 (2), pp. 138-153.

KYMLICKA Will (1995) Multicultural Citizenship: A Liberal Theory of Minority Rights, Oxford, Clarendon Press, 296 p.

LANDOLT Patricia and DA Wei W. (2005) The Spatially Ruptured Practices of Migrant Families: A Comparison of Immigrants from El Salvador and the Poeple's Republic of China, Current Sociology, 53 (4), pp. 625-653.

LESSENICH Stephan (2008) Die Neuerfindung des Sozialen. Der Sozialstaat im flexiblen Kapitalismus, Bielefeld, Transkript, 172 p.

LEVITT Peggy (2001a) The Transnational Villagers, Berkeley and Los Angeles, University of California Press, 294 p.

LEVITT Peggy (2001b) Transnational Migration: Taking Stock and Future Directions, Global Networks, 1 (3), pp. 195-216.

LEVITT Peggy and WATERS Mary C. (Eds.) (2002) The Changing Face of Home: The Transnational Lives of the Second Generation, New York, Russell Sage Foundation, 408 p.

MARCUS George E. (1995) Ethnography in/of the World System: The Emergence of Multi-Sited Ethnography, Annual Review of Anthropology, 24, pp. 95-117.

MARTIN Philip L. (1991) The Unfinished Story: Turkish Labour Migration to Western Europe: With Special Reference to the Federal Republic of Germany, Geneva, International Labour Office, $140 \mathrm{p}$.

MARTIN Philip L. (2004) Germany: Managing Migration in the Twenty-First Century, in Wayne A. Cornelius, Takeyuki Tsuda, Philip L. Martin and James F. Hollifield Eds., Controlling Immigration. A Global Perspective, Stanford, California, Stanford University Press, pp. 221-253.

ØSTERGAARD-NIELSEN Eva (2003) The Politics of Migrants' Transnational Political Practices, International Migration Review, 37 (3), pp. 760-786.

PAGENSTECHER Cord (1996) Die "Illusion" der Rückkehr: Zur Mentalitätsgeschichte von "Gastarbeit" und Einwanderung, Soziale Welt, 47 (2), pp. 149-179.

PARK Robert E. (1950) Race and Culture, Clencoe, The Free Press, 403 p.

PITKÄNEN Pirkko, IÇDUYGU Ahmet and SERT Deniz (Eds.) (2012, forthcoming) Migration and Transformation: Multi-Level Analysis of Migrant Transnationalism, New York, Springer, $350 \mathrm{p}$.

PORTES Alejandro (2001) Introduction: The Debates and Significance of Immigrant Transnationalism, Global Networks, 1 (3), pp. 181-193.

PORTESAlejandro, GUARNIZO Luis E. andLANDOLT Patricia(1999)The Study of Transnationalism: Pitfalls and Promise of an Emergent Research Field, Ethnic and Racial Studies, 22 (2), pp. 217-237.

SHACHER Ayelet (2006) The Race for Talent: Highly Skilled Migrants and Competitive Immigration Regimes, New York University Law Review, 81 (1), pp. 148-206.

VERTOVEC Steven (2009) Transnationalism, London, Routledge, 216 p.

VERTOVEC Steven and WESSENDORF Susanne (2010) Introduction: Assessing the Backlash against Multiculturalism in Europe, in Steven Vertovec and Susanne Wessendorf Eds., The Multicultural Backlash: European Discourses, Policies and Practices, London and New York, Routledge, pp. 1-31. 


\title{
From Return-Oriented to Integration-Related Transnationalisation: Turkish Migrants in Germany
}

\author{
Jürgen Gerdes and Eveline Reisenauer
}

This article examines the relationship between transnational and integration-related practices of Turkish migrants in Germany on the basis of empirical data from the TRANS-NET project. The authors discuss well-known existing concepts of migrant incorporation (assimilation, multiculturalism, transnationalisation) and their relationships, and use their own research results to argue for a combination of these approaches. The analysis of qualitative interviews reveals a remarkable shift from return-oriented to integration-related transnationalisation among Turkish migrants in Germany, a shift that is apparently connected to different political and institutional opportunity structures.

\section{D'une orientation au retour à une intégration en lien avec les pratiques transnationales : les migrants turcs en Allemagne \\ Jürgen Gerdes et Eveline Reisenauer}

Cet article examine le mode de relation entre les pratiques transnationales et les pratiques liées à l'intégration des migrants turcs en Allemagne à partir de données empiriques provenant du projet TRANS-NET. Les auteurs discutent d'abord les concepts les plus connus à propos de l'incorporation des migrants (assimilation, multiculturalisme et transnationalisation) et de leurs mutuelles connexions, puis ils argumentent, à partir des résultats de leur recherche, en faveur d'une combinaison de ces notions. L'analyse des entretiens qualitatifs révèle, dans le cas des migrants turcs en Allemagne, une remarquable évolution qui va de l'orientation au retour à une intégration liée aux pratiques transnationales, ce qui semble être en lien avec des opportunités de changements structurels au niveau politique et institutionnel.

\section{De una orientación hacia el regreso a una integración ligada a las prácticas transnacionales: los migrantes turcos en Alemania}

\author{
Jürgen Gerdes y Eveline Reisenauer
}

Este artículo examina la forma de relación entre las prácticas transnacionales y las prácticas relacionadas con la integración de los inmigrantes turcos en Alemania a partir de datos empíricos del proyecto TRANS-NET. Los autores ponen en debate los conceptos existentes más conocidos sobre la incorporación de los migrantes (asimilación, transnacionalismo y multiculturalismo) y sus relaciones mutuas. Posteriormente argumentan a favor de una combinación de estos conceptos a partir de los resultados de sus investigaciones. En el caso de los inmigrantes turcos en Alemania, el análisis de entrevistas cualitativas revela una notable evolución consistente en reconsiderar la integración en relación con prácticas transnacionales, lo cual parece estar vinculado a oportunidades de cambios estructurales a nivel político e institucional. 


\title{
Von rückkehrorientierter zu integrationsbezogener Transnationalisierung: Türkische Migranten in Deutschland
}

\author{
Jürgen Gerdes and Eveline Reisenauer
}

Der Artikel behandelt das Verhältnis von transnationalen und integrationsbezogenen Praktiken von türkischen Migranten in Deutschland auf der Basis von empirischen Daten aus dem Projekt TRANS-NET. Die Autoren diskutieren bereits eingeführte und bekannte Konzepte der Inkorporation von Migranten (Assimilation, Multikulturalismus und Transnationalisierung) und ihre wechselseitigen Verknüpfungen und argumentieren anhand ihrer Forschungsergebnisse für eine Kombination dieser Ansätze. Die Analyse der qualitativen Interviews verdeutlicht eine beachtliche Veränderung von rückkehrorientierter hin zu integrationsbezogener Transnationalisierung im Fall von türkischen Migranten in Deutschland, die mit verschiedenen politischen und institutionellen Opportunitätsstrukturen einhergeht. 